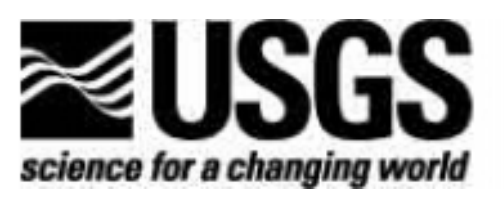

\title{
Relative Coastal Change-Potential Assessment of Kenai Fjords National Park
}

By Elizabeth A. Pendleton, E. Robert Thieler, and S. Jeffress Williams

U.S. Geological Survey Open-File Report 2004-1373

U.S. Department of the Interior

U.S. Geological Survey 


\section{U.S. Department of the Interior Dirk Kempthorne, Secretary}

\section{U.S. Geological Survey Mike D. Myers, Director}

\section{U.S. Geological Survey, Reston, Virginia 2006}

For product and ordering information:

World Wide Web: http://www.usgs.gov/pubprod

Telephone: 1-888-ASK-USGS

For more information on the USGS - the Federal source for science about the Earth, its natural and living resources, natural hazards, and the environment: World Wide Web: http://www.usgs.gov

Telephone: 1-888-ASK-USGS

For Additional Information:

See the National Park Unit Coastal Vulnerability study at http://woodshole.er.usgs.gov/projectpages/nps-cvi/, the National Coastal Vulnerability study at http://woodshole.er.usgs.gov/projectpages/cvi/, or view the USGS online fact sheet for this project in PDF format at http://pubs.usgs.gov/fs/fs095-02/.

Kaloko-Honokohau National Historical Park Web pages are at http://www.nps.gov/kefj/index.htm.

For contacts, see project page at

http://woodshole.er.usgs.gov/project-pages/nps-cvi/; telephone: 508-548-8700

Rebecca Beavers

National Park Service

Natural Resource Program Center

Geologic Resources Division

P.0. Box 25287

Denver, CO 80225-0287

Rebecca_Beavers@nps.gov

Telephone: 303-987-6945

\section{Suggested citation:}

Pendleton, E.A., Thieler, E.R. and Williams, S.J., 2006, Relative Coastal Change-Potential Assessment of Kenai Fjords National Park: U.S. Geological Survey Open-File Report 2004-1373, Web Only. Available online at http://pubs.usgs.gov/of/2004/1373.

Any use of trade, product, or firm names is for descriptive purposes only and does not imply endorsement by the U.S. Government.

Although this report is in the public domain, permission must be secured from the individual copyright owners to reproduce any copyrighted material contained within this report. 


\section{Contents}

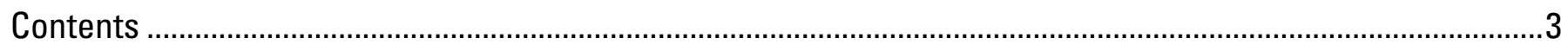

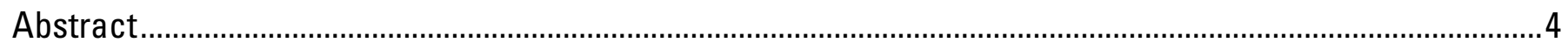

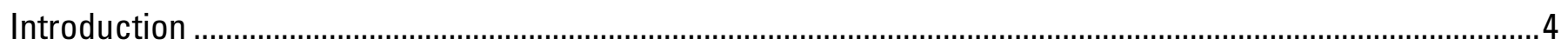

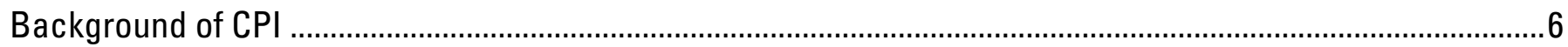

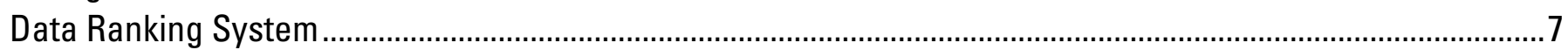

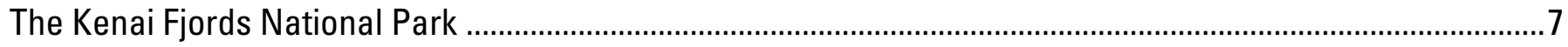

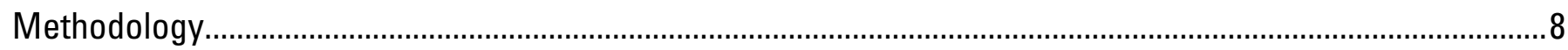

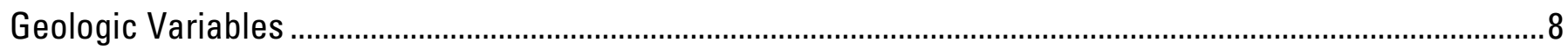

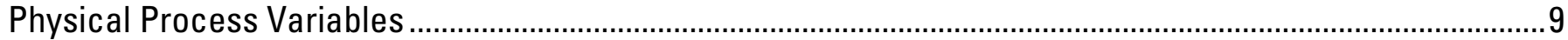

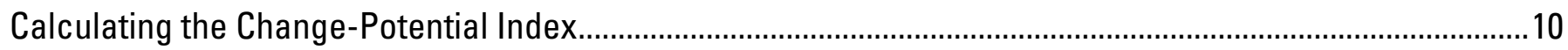

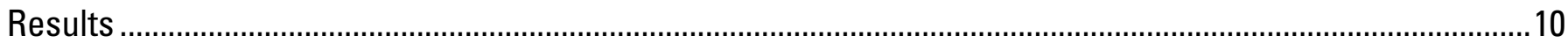

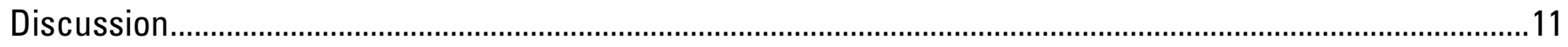

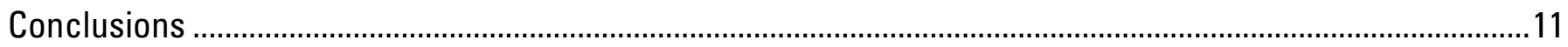

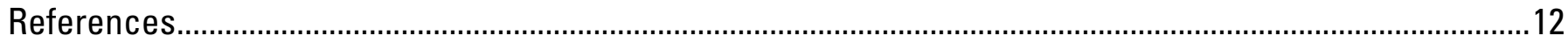

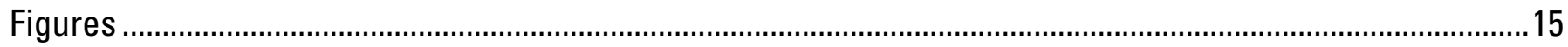

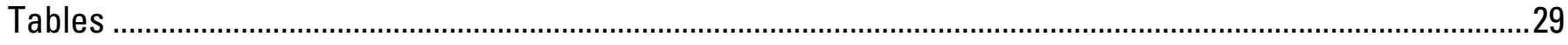




\title{
Relative Coastal Change-Potential Assessment of Kenai Fjords National Park
}

\author{
Elizabeth A. Pendleton, E. Robert Thieler, and S. Jeffress Williams
}

\begin{abstract}
A change-potential index (CPI) was used to map the relative coastal change-potential of the shoreline to future sea-level changes within Kenai Fjords National Park (KEFJ) in south-central Alaska. The CPI ranks the following parameters in terms of their physical contribution to coastal change: geomorphology, regional coastal slope, rate of relative sea-level change, historical shoreline change rates, mean tidal range, and mean significant wave height. The rankings for each input variable were combined, and an index value was calculated for 1-minute grid cells covering the park. The CPI highlights those regions where the physical effects of sea-level and coastal changes might be the greatest. This multi-parametric approach combines the coastal system's potential for change with its natural ability to adapt to changing environmental conditions, yielding a quantitative, although relative, measure of the park's natural susceptibility to the effects of sealevel variation. The CPI provides an objective technique for evaluation and long-term planning by scientists and park managers. The CPI was developed from a Coastal Vulnerability Index (CVI) typically applied to coastlines undergoing long-term sea-level rise. The CPI is modified from the CVI and applied to the emergent coast of Kenai Fjords National Park to understand the limits of applying this type of assessment method in a variety of sea-level settings. Kenai Fjords National Park consists of sand and gravel beaches, rock cliffs, calving tidewater glaciers, mudflats, and alluvial fans. The areas within Kenai Fjords National Park that are likely to be most susceptible to coastal change as a result of sea-level change are tidewater glaciers and outer coast shorelines of unconsolidated sediment where shoreline erosion potential is high and wave energy is high.
\end{abstract}

\section{Introduction}

The U.S. National Park Service (NPS) is responsible for managing nearly $12,000 \mathrm{~km}(7,500$ miles) of shoreline along oceans and lakes. In 2001, the U.S. Geological Survey (USGS), in partnership with the NPS Geologic Resources Division, began conducting assessments of future sea-level changes by producing maps to assist NPS in managing its valuable coastal resources. This report presents the results of a potential for coastal-change assessment for Kenai Fjords National Park, highlighting areas that are likely to be most affected by future changes in sea level and resulting changes on the coastline.

Global sea level has risen approximately 18 centimeters ( 7.1 inches) during the past century (Douglas, 1997). Climate models predict an additional rise of $48 \mathrm{~cm}$ (18.9 in.) by 2100 (IPCC, 2002), which is more than double the rate of rise for the 20th century. Sea level is rising relative to the land surface in more than 74 percent of the locations where there are water level recording stations worldwide (fig. 1). In the United States more than 85 percent of the coastline is experiencing a relative increase in sea level (PSMSL, 2005). The Kenai Peninsula is among a small percentage of the world's coastline experiencing a decrease in relative sea-level caused by uplift of 
the land through post-seismic adjustments following the 1964 Good Friday Earthquake (Brown and others, 1977; Cohen and Freymueller, 1997; 2001). Potential coastal impacts of sea-level fall include dewatering and reduction in water quality of wetlands and estuaries, decrease in harborage area, channel shoaling, increased dredging needs, subaerial exposure of polluted marine sediments, formation and deepening of gullies and erosion near rivers and streams associated with base-level changes, and habitat loss. The Great Lakes and the Dead Sea are examples of areas where resource managers must try to mitigate impacts associated with decreasess in water levels (U.S. Global Change Research Program, 2000; Hassan and Klein, 1999).

The predicted accelerated rise in global sea-level has generated a need in coastal geology to determine the likely response of a coastline to sea-level change. An accurate and quantitative approach to predicting coastal change is difficult to accomplish. Even the types of data necessary to predict shoreline response are the subject of scientific debate. A number of predictive approaches that primarily focus on the impacts of sea-level rise have been proposed (National Research Council, 1990 and 1995), including the following:

1. extrapolation of historical data (e.g., coastal erosion rates),

2. static inundation modeling,

3. application of a simple geometric model (e.g., the Bruun Rule),

4. application of a sediment dynamics/budget model, or

5. Monte Carlo (probabilistic) simulation based on parameterized physical forcing variables.

However, each of these approaches has limitations or can be invalid for certain applications (National Research Council, 1990). Additionally, shoreline response to sea level is further complicated by human modification of the natural coast, such as beach nourishment projects and engineered structures, such as seawalls, revetments, groins, and jetties. Understanding how a natural or modified coast will respond to sea-level change is essential to preserving coastal resources.

The primary challenge in predicting shoreline response to sea-level change is quantifying the important variables that contribute to coastal evolution at a given location. In order to address the multi-faceted task of predicting the impact of sea-level change, the USGS has developed and implemented a methodology to identify areas that may be most likely to experience coastal change (Thieler and Hammar-Klose, 1999). This technique known as the CVI utilizes different ranges of vulnerability (low to very high) to describe a coast's susceptibility to physical change as sea level rises. The coastal vulnerability index was modified for coasts where sea level is falling and a slightly different index was developed, the coastal change-potential index (CPI). The CPI used here focuses on the same six variables as the CVI that strongly influence coastal evolution:

1. Geomorphology

2. Historical shoreline change rate

3. Regional coastal slope

4. Relative sea-level change

5. Mean significant wave height

6. Mean tidal range

These variables can be divided into two groups: 1) geologic variables and 2) physical process variables. The geologic variables are geomorphology, historic shoreline change rate, and coastal slope; they account for a shoreline's relative resistance to erosion, long-term 
erosion/accretion trend, and its susceptibility to flooding or subaerial exposure, respectively. The physical process variables include significant wave height, tidal range, and sea-level change, all of which contribute to the process-induced changes on a particular section of coastline over time scales from hours to centuries. A relatively simple change-potential ranking system (table 1) allows the six variables to be incorporated into an equation that produces a change-potential index (CPI). The CPI can be used by scientists and park managers to evaluate the likelihood that physical change may occur along a shoreline as sea level continues to change. Additionally, NPS staff will be able to incorporate information provided by this change-potential assessment technique into general management plans.

\section{Background of CPI}

The Change-Potential Index (CPI) for assessing susceptibility to coastal change associated with a decrease in sea level was derived from a similar methodology called the Coastal Vulnerability Index (CVI), which was developed to highlight the vulnerability of a coast a rise in sea-level (Thieler and Hammar-Klose, 1999). Potential impacts associated with sea-level rise include shoreline erosion, saltwater intrusion into groundwater aquifers, inundation of wetlands and estuaries, and threats to cultural and historic resources as well as infrastructure. Impacts from sealevel fall in an area such as south-central Alaska could include grounding of tidewater glaciers, dewatering of wetland areas, decrease in harborage area, channel shoaling, stream and river mouth erosion, and habitat loss. A goal of the USGS/NPS cooperative project was to apply the CVI methodology in a variety of sea-level settings, and Kenai Fjords National Park was selected as a location where relative sea-level is falling. Because the impacts associated with a decrease in sealevel are different from impacts associated with a rise in sea-level, a slightly different index was developed to differentiate assessments in areas with falling sea-level from areas experiencing sealevel rise. In this study, we considered that impacts are often evaluated from a human perspective and a human connection to the coast. Threats to infrastructure, for example, are a major concern along coastlines that are experiencing a rise in sea-level. Alternatively, the potential subaerial exposure of polluted marine sediments may be a primary concern in areas where sea level is falling. For the purposes of this cooperative project, we chose to reserve the word 'vulnerability' for coastlines that may experience loss of land, infrastructure, or natural and cultural resources as a result of sea-level rise. Alternatively, for areas where sea level is falling and associated impacts are not as well-understood or researched, we address the likelihood that coastal change may occur without assigning a subjective term such as risk, hazard, or vulnerability.

One assumption that is made in order to apply the CPI method to an emerging coast is that independent of the net movement of sea level relative to the land surface, the variables that are most important to coastal change and shoreline evolution will be the same. That is, the six variables defined in the CPI methodology will be important for both submergent (experiencing relative sealevel rise) and emergent (experiencing relative sea-level fall) coastlines. Because the CPI is designed to highlight change-potential based on variables that are common to almost all coasts without directly indicating a physical effect, it should be amenable to application in a variety of geologic settings. Although this methodology can be applied anywhere that physical change is likely to occur as a result of changing sea-level, the kinds of change that may occur are not addressed and should be considered by planners in the context of resources utilization and preservation. This report confirms that the CPI methodology can be applied to the Kenai Fjords NP coastline. The usefulness of the data for planning purposes, however, will be a function of the nature of potential environmental change and whether such change is desirable from a resourcemanagement perspective. 


\section{Data Ranking System}

Table 1 shows the six variables described in the Introduction and includes both quantitative and qualitative information. The five quantitative variables are assigned a change-potential ranking based on their actual values, whereas the non-numerical geomorphology variable is ranked qualitatively according to the relative resistance of a given coastal landform to erosion. Shoreline change-potential is estimated using the relative resistance of the landform to erosion and the wave energy in the area. Rock-cliff areas are assigned low shoreline change-potential regardless of wave energy, because rock cliffs are not likely to experience significant erosion or accretion annually. Unconsolidated sediments within fjords are classified as moderate shoreline change-potential. Beaches along the exposed coast and areas where the termini of glaciers reach to or near the shoreline are classified as high shoreline change-potential. Regional coastal slopes range from very high change-potential, $<4.59$ percent, to very low change-potential at values $>14.7$ percent. The rate of relative sea-level change is ranked such that no change in sea level $\left(0 \mathrm{mma}^{-1}\right)$ up to the modern rate of eustatic rise $\left(1.8 \mathrm{mma}^{-1}\right)$ as very low change-potential. Since the global (eustatic) or "background" rate is common to all shorelines, the sea-level ranking reflects primarily local to regional isostatic or tectonic adjustment. Wave energy regime contributions to change-potential range from low within fjords to high along the outer coast. Tidal range is ranked such that microtidal $(<1 \mathrm{~m})$ coasts are very high change-potential and macrotidal $(>6 \mathrm{~m})$ coasts are very low change-potential.

\section{The Kenai Fjords National Park}

The rocky, cliffed coast of Kenai Fjords National Park lies along the southeastern side of the Kenai Peninsula in south-central Alaska (fig. 2). This region of the Kenai Peninsula is part of the Chugach terrane that collided with Alaska about 65 million years ago; the bedrock is primarily composed of partially metamorphosed muddy sandstones and shales from turbidite deposit with intrusions of granite and granodiorite (Beikman, 1980) (fig. 3A) The Harding Icefield sits astride the Kenai Mountains and supplies ice to outlet glaciers that carve deep U-shaped valleys into the soft bedrock (fig. 2). For more information on the geology of south-central Alaska please see the following:

http://www.alaskageography.com/maps/maps.htm.

In addition to the tectonic activity associated with accreting terranes along south-central Alaska, the advance and retreat of glacier ice throughout the Pleistocene Epoch (fig. 3B) has caused significant sea-level fluctuations along the coast of the Gulf of Alaska. Alpine glaciers may have appeared in the mountains of south-central Alaska between 10 and 13 million years ago and many of these areas have remained ice covered for at least the past five million years (Connor and O'Haire, 1988). Deep valleys carved by glaciers during glacial maxima are now flooded creating irregular shorelines such as Kenai Fjords National Park. Presently, waves and tides further modify this glacier-eroded coastline creating a variety of geomorphologic features along the coast including sand and gravel pocket beaches, tidewater glaciers, rock cliffs, mud flats, and sea arches and stacks.

The affects of climate change on glaciers and icefields are a primary concern for Kenai Fjords NP. Because the focus of this project is potential change to the shoreline of Kenai Fjords NP with regard to changing sea level, the change in glacier ice is not considered unless the glacier terminus calves in the ocean (tidewater glacier). Change in the Harding Icefield and changes in glacier area and termini within the park are discussed in Hall and others (2005). Changes in outlet glacier termini and volume are discussed in Adalgeirsdottir and others (1998). Additional information on a variety of climate change impacts and hazards in Alaska and the Arctic is found in ACIA (2005). 
Other hazards that can result in immediate and major coastal and sea-level change along Kenai Peninsula include earthquakes, tsunamis, and landslides. In 1964, a magnitude 9.2 earthquake shook south-central Alaska and resulted in six feet of coseismic land subsidence along the Kenai Fjords NP coastline (Plafker, 1971). However, in the decades (1964 - 1995) following the earthquake, the Kenai Fjords NP shoreline is estimated to have experienced between 20 and $40 \mathrm{~cm}$ of post-seismic tectonic uplift (fig. 4). Uplift rates have been determined from GPS measurements and water level recorders (Cohen and Freymueller, 1997; Cohen and Freymueller, 2001). Most areas on Kenai Peninsula (including Kenai Fjords NP) are emerging at a rate faster than the rise of eustatic (global) sea-level $(1.8 \mathrm{~mm} / \mathrm{yr})$, which is unique when compared to most of the world's coastline (fig. 1).

Nearly 25 years after the 1964 Good Friday Earthquake, a major environmental accident affected south-central Alaska. On 24 March 1989 the 300-m (987-foot) long supertanker Exxon Valdez grounded on Bligh Reef in Prince William Sound spilling nearly 11 million gallons of crude oil and impacting more than 1,100 miles of pristine shoreline. The coastal impacts of such an incident are still being determined, because it is the largest oil spill in U.S. history and the longterm affects are still uncertain. Additional information on the 1989 Exxon Valdez oil spill in Prince William Sound can be found at the following: http://oceanservice.noaa.gov/education/stories/oilymess/welcome.html

\section{Methodology}

In order to develop a database for a park-wide assessment of coastal change-potential, data for each of the six variables mentioned above were gathered from state and federal agencies (table 2). The database is based on the one used by Thieler and Hammar-Klose (1999) and loosely follows an earlier database developed by Gornitz and White (1992). A comparable assessment of the sensitivity of the Canadian coast to sea-level rise is presented by Shaw and others (1998). The database was constructed using a 1:63,360-scale shoreline of Kenai Fjords NP that was created from USGS 1:63,360 quadrangles (1950-1990) and obtained from the National Park Service, Alaska Support Office, GIS Data Clearinghouse [http://www.nps.gov/akso/gis/]. Data for each of the six variables (geomorphology, shoreline change, coastal slope, relative sea-level change, significant wave height, and tidal range) were added to the shoreline attribute table using a 1minute (approximately $1.5 \mathrm{~km}$ ) grid (fig. 5). Next, each variable in each grid cell was assigned a change-potential value from 1-5 (1 is very low change-potential, 5 is very high change-potential) based on the potential magnitude of its contribution to physical changes on the coast in response to sea level changes (table 1).

\section{Geologic Variables}

The geomorphology variable expresses the relative erodibility of different landform types (table 1). These data were derived using a database that was created to depict shore-zone classification determined from analysis of 1:12,000-scale black-and-white vertical aerial photographs (Mann, 1997) [http://www.nps.gov/akso/gis/]. In addition, field visits were made to accessible locations of the park to verify the accuracy of the classification (fig. 6A-G). Description in the book Living with the Coast of Alaska (Mason and others, 1997) were also used to help constrain the geomorphologic classification. Kenai Fjords NP contains several coastal landform types, including low to very low change-potential rock cliffs, moderate change-potential alluvial and glacial deposits, high change-potential gravel beaches and very high change-potential mudflats, sand beaches, and tidewater-glacier termini (fig. 6A-G, fig. 7).

Shoreline erosion and accretion potential for Kenai Fjords was estimated from data contained in the shore-zone classification database and wave energy regime information (table 2) 
(Mann 1995, 1997;Crowell and Mann, 1995). Shoreline change-potential was estimated based on whether the shoreline was consolidated or unconsolidated and the amount of wave energy expended on the shore. Because the shoreline change-potential data was derived qualitatively from existing datasets, the categories for shoreline change-potential were limited to high, moderate, and low. Shoreline change-potential was not assigned to the very low or very high categories. Rock cliff areas were assigned low shoreline change-potential regardless of wave energy, because rock cliffs are not likely to experience significant erosion or accretion annually. Unconsolidated sediments within fjords were generally classified as moderate shoreline change-potential. Beaches along the exposed coast and areas where glaciers reached at or near the shoreline were classified as high change-potential. The shoreline change-potential within each 1-minute grid cell was averaged to determine the shoreline change-potential used here. Shoreline change-potential for Kenai Fjords NP ranges from low change-potential (areas not likely to experience significant shoreline change annually) to high change-potential (areas where shoreline change will likely occur within one year) (fig. 8).

Regional coastal slope is an indication of the relative vulnerability to inundation and the potential rapid rate of shoreline retreat, because low-sloping coastal regions should retreat faster than steeper regions (Pilkey and Davis, 1987). The regional slope of the coastal zone was calculated from a grid of topographic and bathymetric elevations extending $10 \mathrm{~km}$ landward and seaward of the shoreline. Elevation data were obtained from the National Geophysical Data Center (NGDC) as gridded topographic and bathymetric elevations at 0.1-meter vertical resolution for 1minute grid cells. Regional coastal slopes for Kenai Fjords NP fall within the very low to very high change-potential category ( $<4.55 \%->14.7 \%$ ) (fig. 9).

\section{Physical Process Variables}

The relative sea-level change variable is derived from the change in annual mean water elevation over time as measured at tide gage stations along the coast. The rate of sea-level change for Seward, AK is $-1.46+0.67 \mathrm{mma}^{-1}$ based on 36 years of data since the Good Friday Earthquake of 1964 (Zervas, 2001). This variable inherently includes both eustatic sea-level change (addition of glacier meltwater and static increase in volume) as well as regional sea-level change caused by isostatic and tectonic adjustments of the land surface. Relative sea-level change data are limited to the historical record, and thus portray only the recent sea-level trend ( $<150$ years). Relative sealevel change for Kenai Fjords NP falls within very low change-potential based on water elevation data at Seward, AK (fig. 10).

Kenai Peninsula is still experiencing complex post-seismic tectonic uplift from the 1964 Good Friday Earthquake. Uplift in some areas on the western edge of the Kenai Peninsula experienced rates near $30 \mathrm{mma}^{-1}$ in the early decades following the earthquake (Cohen and Freymeuller, 2001) (fig. 4). However, such high rates of uplift are not expected to persist, and GPS measurements between 1993 and 1995 recorded uplift to be comparatively small and likely due to steady plate convergence rather than continued post-seismic tectonic rebound (Cohen and Freymeuller, 1997; 2001). For this reason and also because of the documented suspect tide gage data at Nikiski, AK, all of Kenai Fjords NP sea-level data were mapped to the gage at Seward, AK (Zervas, 2001; Cohen and Freymeuller, 1997). Other tide gages, such as Kodiak Island, Seldovia, and Valdez are significantly further from the study area and likely influenced by tectonic processes that are likely not relevant to tectonic processes within Kenai Fjords NP.

Mean significant wave height is used here as a proxy for wave energy which drives coastal sediment transport. Wave energy is directly related to wave height: 
$E=1 / 8 \rho g H^{2}$

where $\mathrm{E}$ is energy density, $\mathrm{H}$ is wave height, $\rho$ is water density and $\mathrm{g}$ is acceleration due to gravity. Thus, the ability to mobilize and transport coastal sediments is a function of wave height squared. Recorded significant wave height values are used for this variable where available. However, significant wave height data were not available for all parts of Kenai Fjords National Park, so a wave energy regime database produced by the USGS and available through NPS was used instead (Mann 1995; Crowell and Mann, 1995) (http://www.nps.gov/akso/gis/). For Kenai Fjords NP, areas in low wave-energy regimes were assigned low change-potential, while moderate wave-energy regimes were assigned moderate change-potential, and high wave-energy regimes were classified as high change-potential (fig. 11).

Tidal range is linked to both permanent and episodic inundation hazards. Tide-range data were obtained from NOAA/NOS published benchmarks from Resurrection Bay, Agnes Cove, Bear Cove, North Aialik, Aialik Sill, Camp Cove, and Crater Bay. All mean tidal ranges fell between 2.54 and $2.87 \mathrm{~m}$, therefore classified as moderate change-potential (2.0 - 4.0 meters $)$ with respect to tidal range (fig. 12).

\section{Calculating the Change-Potential Index}

The coastal change-potential index (CPI) employed here is the same as that used in Thieler and Hammar-Klose (1999) and is similar to that used in Gornitz and others (1994), as well as to the sensitivity index employed by Shaw and others (1998). The CPI allows the six variables to be related in a quantifiable manner that expresses the relative change-potential of the coast to physical changes due to future sea-level change. This method yields numerical data that cannot be equated directly with particular physical effects. It does, however, highlight areas where the various effects of sea-level change may be the greatest. Once each section of coastline is assigned a changepotential value for each specific data variable, the coastal change-potential index (CPI) is calculated as the square root of the product of the ranked variables divided by the total number of variables;

$\mathrm{CPI}=\sqrt{\frac{\left(a^{*} b^{*} c^{*} d^{*} e^{*} f\right)}{6}}$

where, $\mathrm{a}=$ geomorphology, $\mathrm{b}=$ shoreline erosion/accretion rate, $\mathrm{c}=$ coastal slope, $\mathrm{d}=$ relative sealevel rise rate, $\mathrm{e}=$ mean significant wave height, and $\mathrm{f}=$ mean tide range. The calculated CPI value is then divided into quartile ranges to highlight different change-potentials within the park. The CPI ranges (low - very high) reported here apply specifically to KEFJ, and are not comparable to CPI ranges in other parks where the CPI has been employed (i.e., very high change-potential means the same among parks; it's the numeric values that differ, such that a numeric value that equals very high change-potential in one park may equal moderate change-potential in another). To compare change-potential between coastal parks, the national-scale studies should be used (Thieler and Hammar-Klose, 1999, 2000a, and 2000b). We feel this approach best describes and highlights the coastal change-potential specific to each park.

\section{Results}

The CPI values calculated for Kenai Fjords range from 1.14 to 12.6. The mean CPI value is 4.09; the mode is 4.90 and median is 4.0. The standard deviation is 1.7 . The 25 th, 50 th, and 75 th percentiles are $2.9,4.1$ and 4.75 , respectively. 
Figure 13 shows a map of the coastal change-potential index for Kenai Fjords National Park. The CPI scores are divided into low, moderate, high, and very high-change-potential categories based on the quartile ranges and evaluation of the data. CPI values $<2.9$ are assigned to the low change-potential category. Values from 2.9 to 4.1 are considered moderate changepotential. High change-potential values are between 4.11 and 4.75. CPI values above 4.75 are classified as very high change-potential. Figure 14 shows the percentage of Kenai Fjords shoreline in each change-potential category. Nearly $700 \mathrm{~km}$ (430 miles) of shoreline is evaluated along the Kenai Fjords NP shoreline. Of this total, seventeen percent of the mapped shoreline is classified as being at very high change-potential with respect to future sea-level change. Thirty-five percent is classified as high change-potential, twenty-five percent as moderate change-potential, and twentythree percent as low change-potential.

\section{Discussion}

The data within the coastal change-potential index (CPI) show variability at different spatial scales (fig. 13). However, the ranked values for the physical process variables vary less over the extent of the shoreline. The value of the relative sea-level rise variable is constant at very low change-potential for the entire study area. The significant wave height change-potential is low to high. The tidal range is moderate change-potential $(2.0-4.0 \mathrm{~m})$ for all of Kenai Fjords NP.

The geologic variables show the most variability and thus have the most influence on the CPI (fig. 13). Geomorphology in the park includes very high change-potential sandy beach shoreline, high change-potential gravel beaches, moderate change-potential alluvial fans and glacial landforms, low and very low change-potential rock and cliff features (fig. 6A-G and fig. 7). Change-potential based on shoreline change estimates varies from low to high (fig. 6A-E). Regional coastal slope is in the very low to very high change-potential range for Kenai Fjords NP. The most influential variables in the CPI are geomorphology, shoreline change-potential, coastal slope, and wave energy; therefore, they may be considered the most important variables controlling how Kenai Fjords will evolve as sea level changes.

\section{Conclusions}

The coastal change-potential index $(C P I)$ provides insight into the relative potential of coastal change resulting from future sea-level change. The maps and data presented here can be viewed in at least two ways:

1. as an indication of where physical changes to the coast are most likely to occur as sea level changes; and

2. as a planning tool for the optimum management of Kenai Fjords National Park's natural and cultural resources.

As ranked in this study, geomorphology, shoreline change-potential, regional coastal slope and wave energy and are the most important variables in determining the CPI for Kenai Fjords NP. Tidal range and the current sea-level change do not contribute to the variability in the coastal change-potential index.

Kenai Fjords National Park preserves a dynamic natural environment, an environment which must be understood in order to be managed properly. The CPI is one way that park managers can assess objectively the natural factors that contribute to the evolution of the coastal zone, and thus how the park may evolve in the future. 


\section{References}

ACIA, 2005, Arctic Climate Impact Assessment, ACIA Scientific Report: New York, Cambridge University Press, 1042 p. Available online at http://amap.no/acia/.

Adalgeirsdottir, G., Echelmeyer, K.A., and Harrison, 1998, Elevation and volume changes on the Harding Icefield, Alaska: Journal of Glaciology, v. 44, no. 148, p. 570-582.

Beikman, H.M., compiler, 1980, Geologic Map of Alaska: U.S. Geological Survey Map SG0002$1 \mathrm{~T}$ and 2T, Scale 1:2,500,000. Also available online at http://agdc.usgs.gov/data/usgs/geology/index.html or http://agdcftp1.wr.usgs.gov/pub/usgs/geology/beikman.tar.gz

Brown, L.D., Reilinger, R.E., Holdahl, S.R., and Balazs, E.I., 1977, Post-seismic crustal uplift near Anchorage, Alaska: Journal of Geophysical Research, v. 82, p. 3369-3378.

Cohen, S.C., and Freymueller, J.T., 1997, Deformation on the Kenai Peninsula, Alaska: Journal of Geophysical Research, v. 102, p. 20, 479-20, 487.

Cohen, S.C., and Freymueller, J.T., 2001, Crustal uplift in the south central Alaska subduction zone; New analysis and interpretation of tide gauge observations: Journal of Geophysical Research, v. 106, no. 6, p. 11,259-11,270.

Connor, C. and O'Haire, D., 1988, Roadside geology of Alaska: Missoula, Montana, Mountain Press Publishing Co., 251 p.

Crowell, A.L., and Mann D.H., 1995, Sea level dynamics, and coastal archaeology in the central Gulf of Alaska, Alaska: Anthropological Association Annual Meeting, Anchorage, Alaska.

Douglas, B.C., 1997, Global sea rise, A redetermination: Surveys in Geophysics, v. 18, p. 279-292.

Gornitz, V. and White, T.W. 1992, A coastal hazards database for the U.S. West Coast: ORNL/CDIAC-81, NDP-043C, Oak Ridge National Laboratory, 162 p.

Gornitz, V.M., Daniels, R.C., White, T.W., and Birdwell, K.R., 1994, The development of a coastal vulnerability assessment database, Vulnerability to sea-level rise in the U.S. southeast: Journal of Coastal Research, Special Issue No. 12, p. 327-338.

Hall, D.K., Giffen, B.A., Chien, J.Y.L., 2005, Changes in the Harding Icefield and the GrewingkYalik Glacier Complex: 62nd Eastern Snow Conference, Waterloo, Ontario, Canada.

Hammar-Klose, E.S., and Thieler, E.R., 2001, Coastal vulnerability to sea-level rise, a preliminary database for the U.S. Atlantic, Pacific, and Gulf of Mexico Coasts: U.S. Geological Survey Digital Data Series DDS-68, CD-ROM. Also available online at http://pubs.usgs.gov/dds/dds68/.

Hassan, M.A., and Klein, M., 1999, Fluvial adjustment of the Lower Jordan River to a drop in the Dead Sea level: Geomorphology, v. 45, no 1-2, p. 21-33. 
IPCC, 2002, Climate change 2001, The scientific basis: Geneva, Switzerland, contribution of working group I; Third Assessment Report of the Intergovernmental Panel on Climate Change (IPCC), 563 p. Also available online at http://www.ipcc.ch/.

Manley, W., 2002, Maximum Pleistocene glacier extents: Alaska PaleoGlacier atlas; GIS data. Available online at http://instaar.colorado.edu/QGISL/data_intro.html. Accessed Sept. 2006.

Mann, D.H., 1995, Wave energy regimes - Kenai Fjords National Park: U.S. Geological Survey Map. Available online at http://agdc.usgs.gov/ or http://www.nps.gov/akso/gis.

Mann, D.H., 1997, Shore-zone classifications of Kenai Fjords National Park: National Park Service, Alaska Support Office Map. Available online at http://agdc.usgs.gov/ or http://www.nps.gov/akso/gis.

Mason, O., Neal, W.J., Pilkey, O.H., Bullock, J., Fathauer, T., Pilkey, D., and Swanston, D., 1997, Living with the coast of Alaska: Durham, North Carolina, Duke University Press, 348 p.

National Research Council, 1990, Managing coastal erosion: Washington, D.C., National Academy Press, 163 p.

National Research Council, 1995, Beach nourishment and protection: Washington, D.C., National Academy Press, 334 p.

NOAA, 2005, Tidal Station Locations and Ranges. Available online at http://coops.nos.noaa.gov/tides05/tab2wc2b.html. Accessed Sept. 2006.

Pilkey, O.H., and Davis, T.W., 1987, An analysis of coastal recession models, North Carolina coast, in Nummedal, D., Pilkey, O.H., and Howard, J.D.,eds., Sea-level fluctuation and coastal evolution: SEPM (Society for Sedimentary Geology) Special Publication No. 41, p. 59-68.

Plafker, G., 1971., Tectonics, in The Great Alaska Earthquake of 1964: Washington, D.C., Geology, National Academy of Sciences, p.47-122.

PSMSL, 2005, Permanent Service for Mean Sea Level. Available online at http://www.pol.ac.uk/psmsl/. Accessed Sept. 2006.

Shaw, J., Taylor, R.B., Forbes, D.L., Ruz, M.H., and Solomon, S., 1998, Sensitivity of the Canadian coast to sea-level rise: Geological Survey of Canada Bulletin 505, 114 p.

Thieler, E.R., and Hammar-Klose, E.S., 1999, National assessment of coastal vulnerability to sealevel rise, U.S. Atlantic Coast: U.S. Geological Survey Open-File Report 99-593, 1 sheet. Available online at http://pubs.usgs.gov/of/of99-593/.

Thieler, E.R., and Hammar-Klose, E.S., 2000a, National assessment of coastal vulnerability to sealevel rise, U.S. Pacific Coast: U.S. Geological Survey Open-File Report 00-178, 1 sheet. Available online at http://pubs.usgs.gov/of/of00-178/. 
Thieler, E.R., and Hammar-Klose, E.S., 2000b, National assessment of coastal vulnerability to sealevel rise, U.S. Gulf of Mexico Coast: U.S. Geological Survey Open-File Report 00-179, 1 sheet. Available online at http://pubs.usgs.gov/of/of00-179/.

U.S. Global Change Research Program, 2000, U.S. national assessment of the potential consequences of climate variability and change: Washington, D.C., U.S. Climate Change Science Program/U.S. Global Change Research Program.

Zervas, C., 2001, Sea level variations of the United States 1854-1999: NOAA Technical Report NOS CO-OPS 36, 201 p. 


\section{Figures}

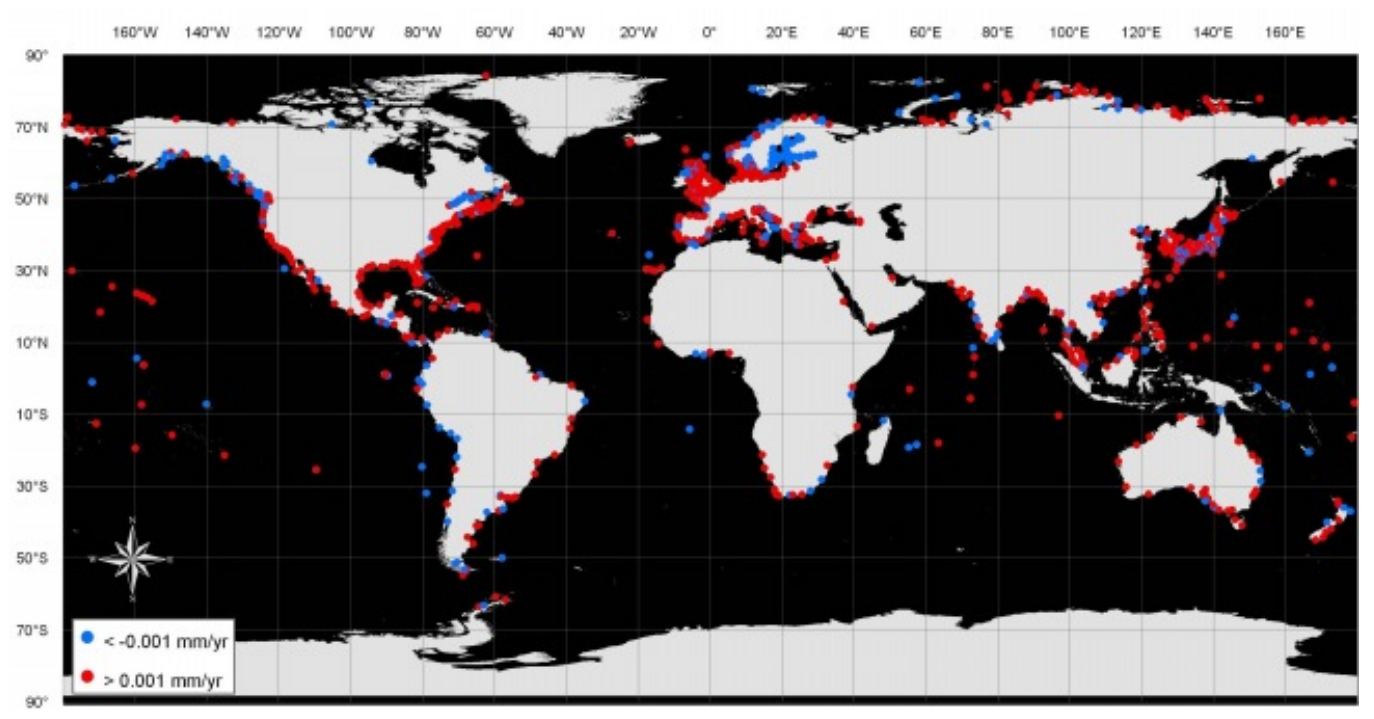

Figure 1. Global distribution of water-level recording stations as reported by the Permanent Service for Mean Sea Level (PSMSL, 2005). Red dots indicate relative increase in sea-level, blue dots indicate a relative decrease in sea-level. Nearly three-quarters of the stations report an increase in sea-level relative to the land surface. 


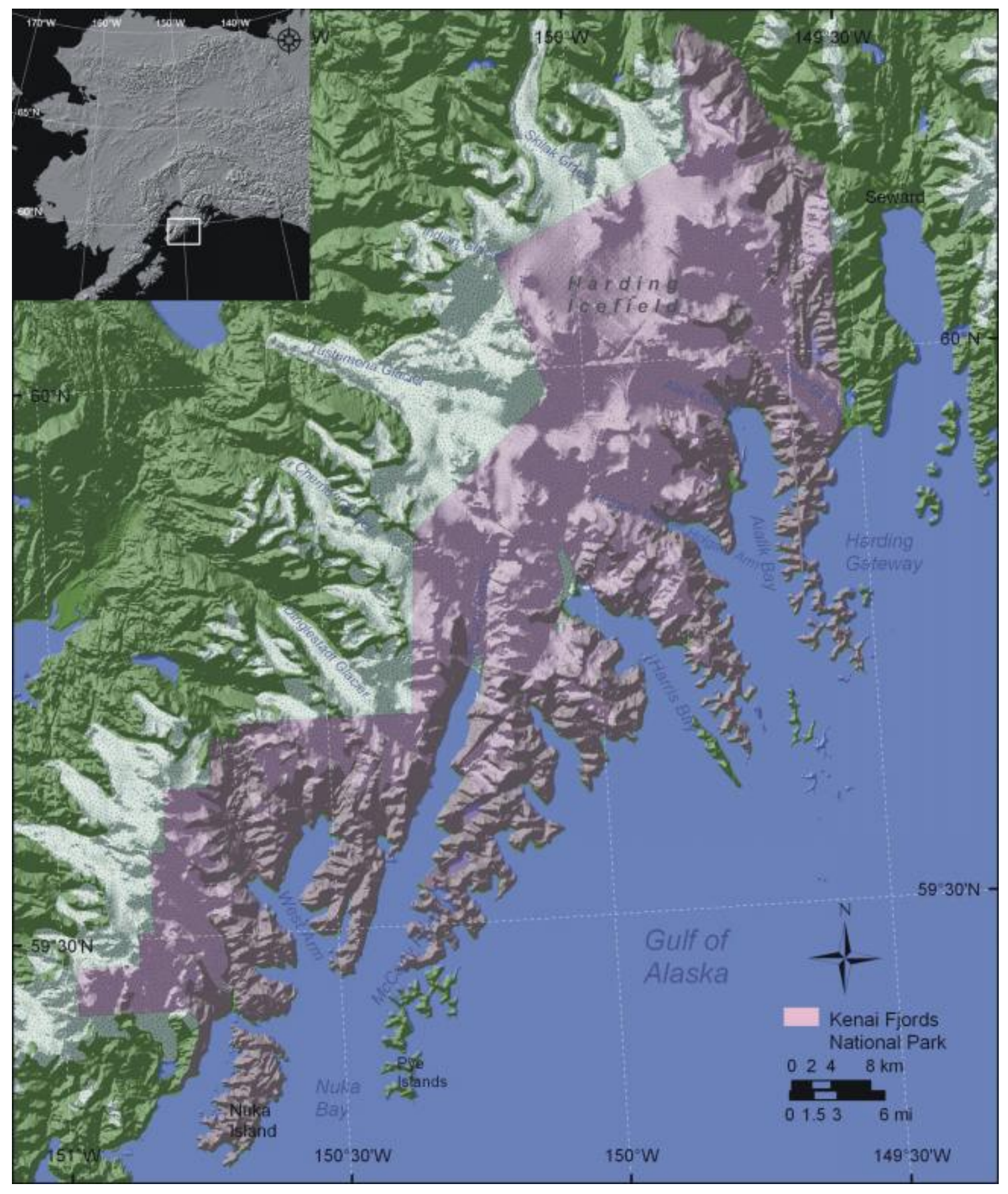

Figure 2. Index map of Kenai Fjords National Park, Alaska. A more detailed map is provided by the National Park Service and can be viewed in digital format at http://www.nps.gov/kefj/planyourvisit/upload/KEFJmap1.pdf. 


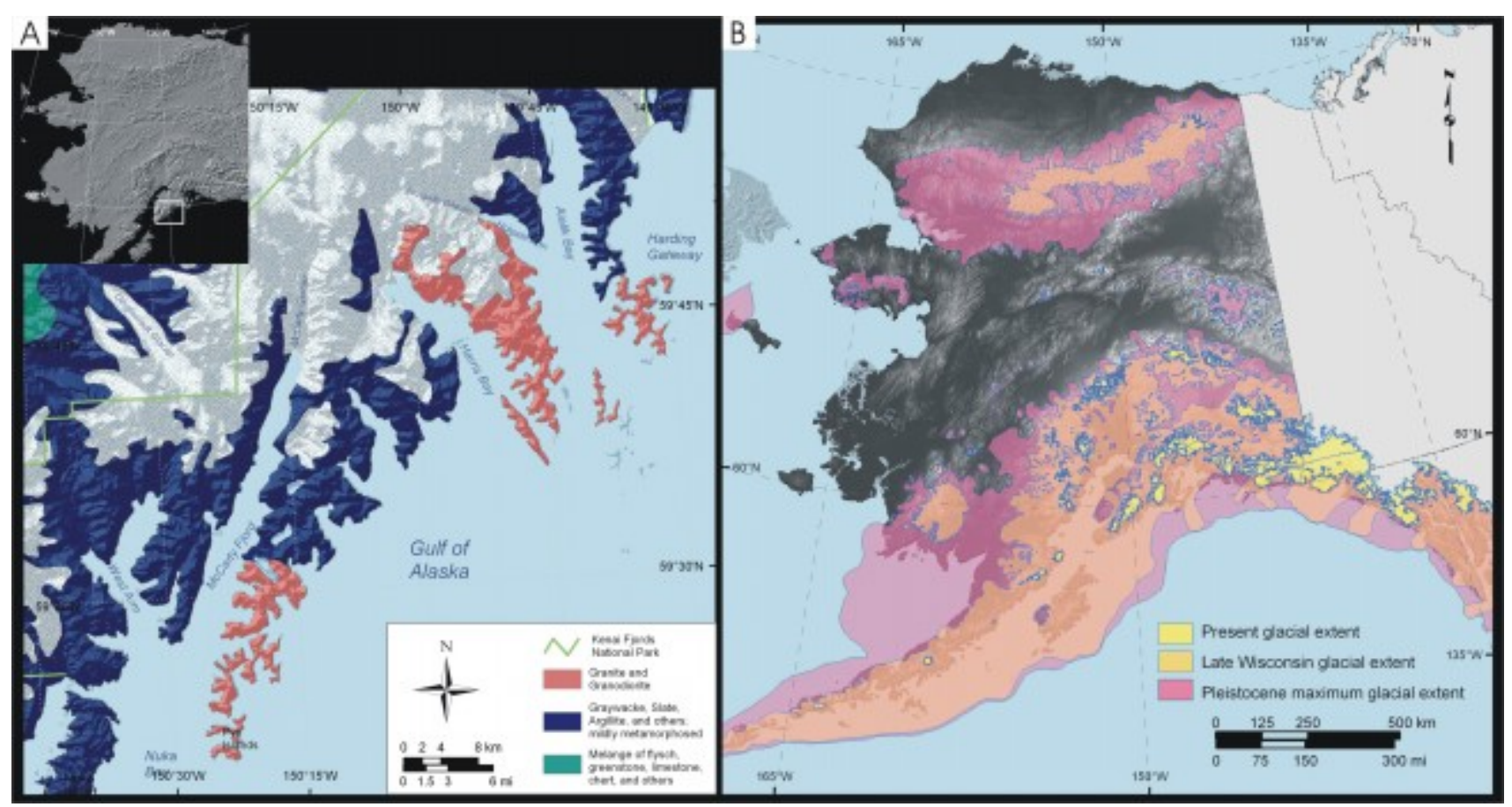

Figure 3. A) Geology of Kenai Fjords National Park. This figure is produced from a USGS Geologic Map of Alaska (Beikman, 1980). The data is available as a GIS layer through the Alaska Geospatial Data Clearinghouse. B) Maximum extent of Pleistocene glaciations and present-day glaciers in Alaska. These data are available as GIS layers through the Alaska PaleoGlacier Atlas (Manley, 2002). 


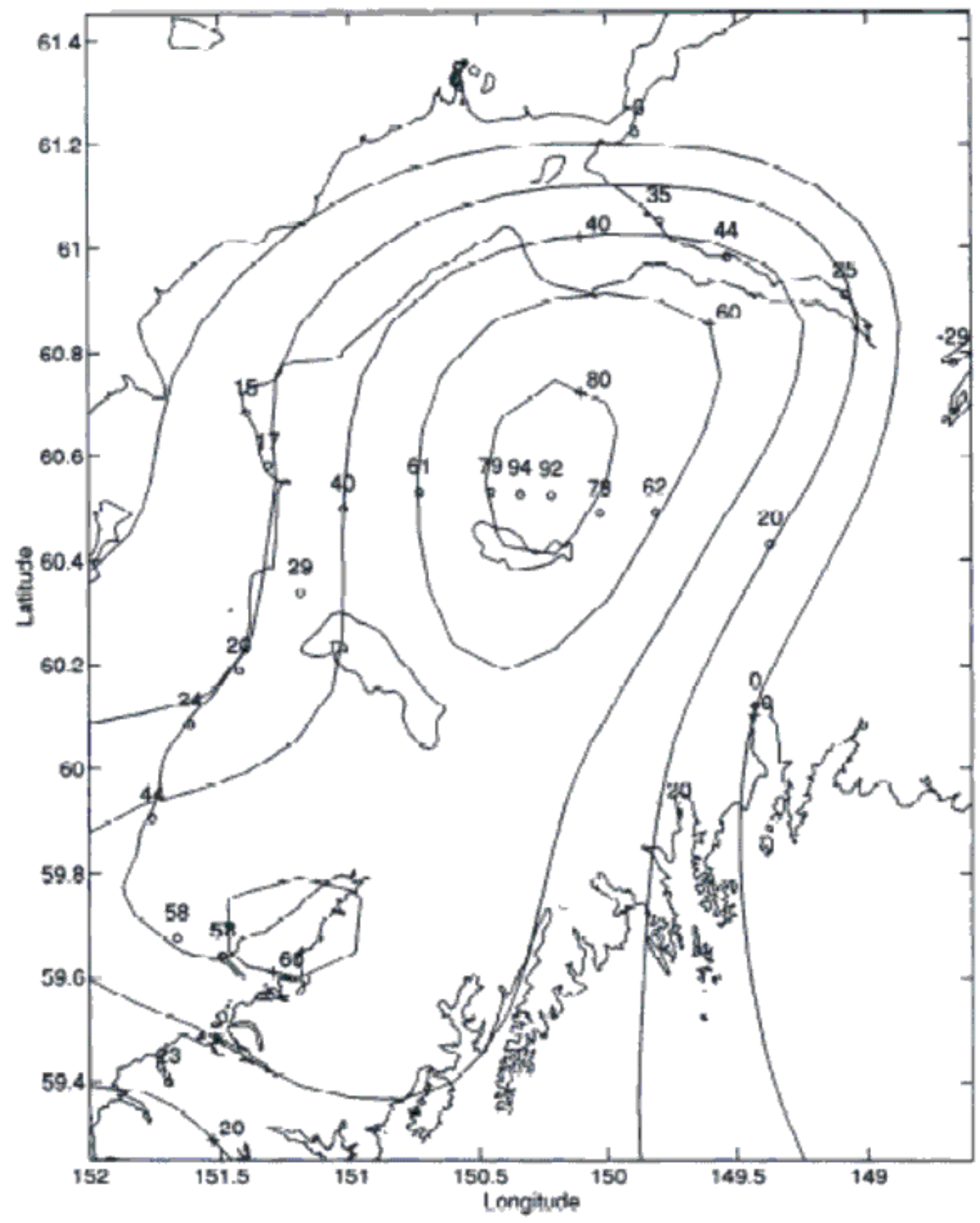

Figure 4. Regional cumulative post-seismic uplift from GPS measurements and tide gauges as determined by Cohen and Freymueller: 1964-1995. Contours and point values are in $\mathrm{cm}$. Figure from Cohen and Freymueller (1997). 


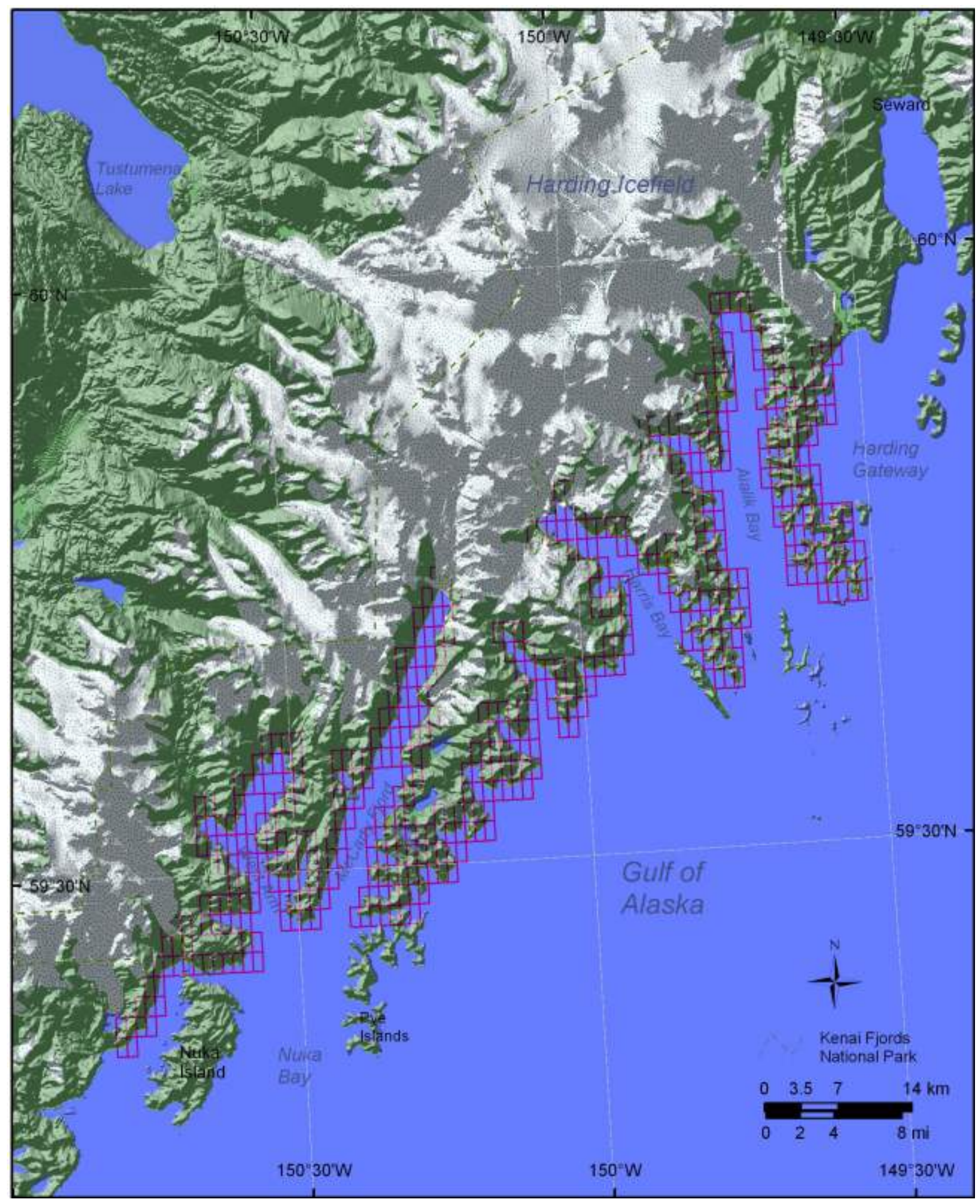

Figure 5. Shoreline grid for Kenai Fjords National Park. Each cell is approximately 1-minute of shoreline and represents a shoreline segment for which each of the six variables are defined. 

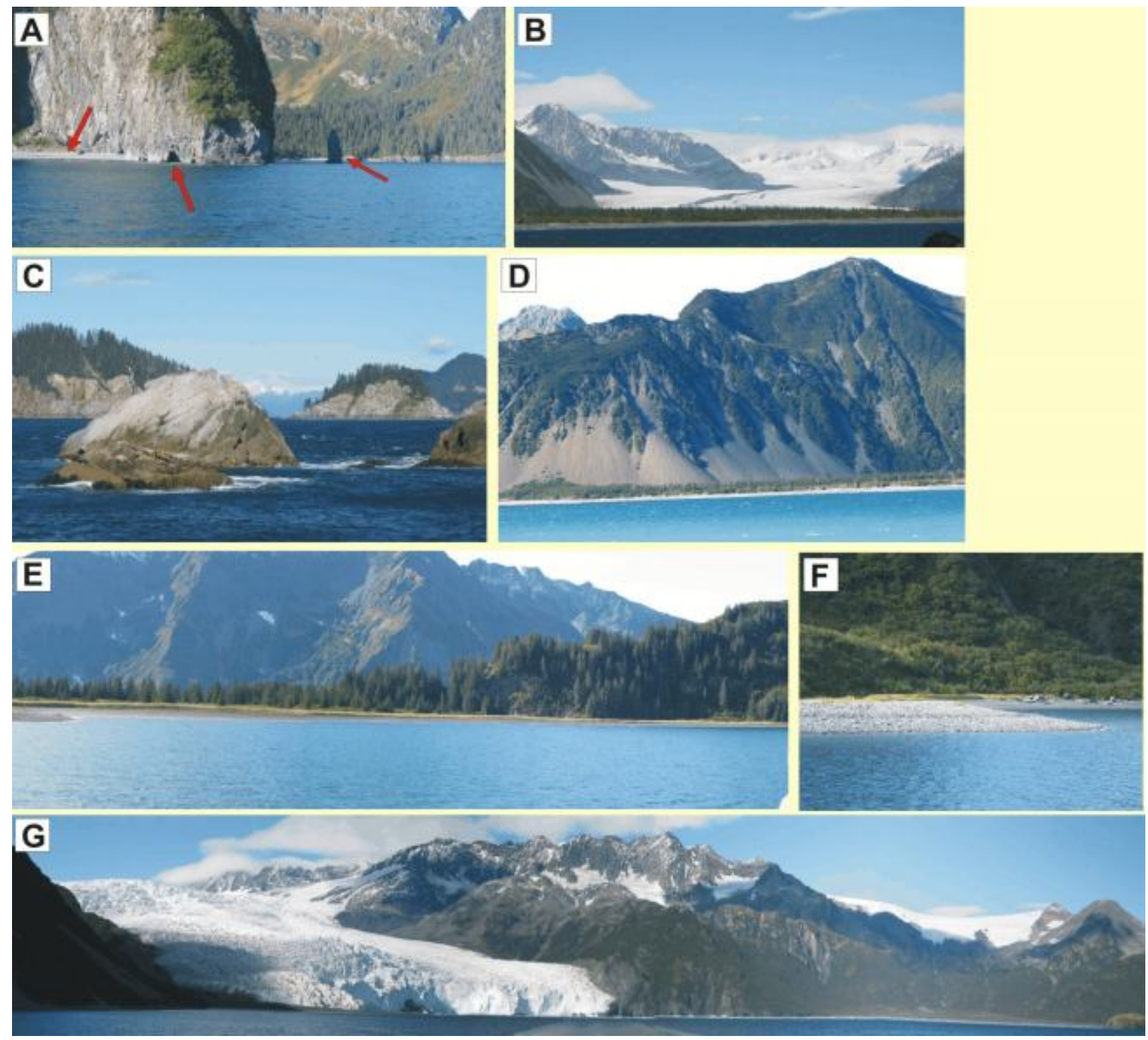

Figure 6. Seven ground photographs of representative coastal landforms within Kenai Fjords National Park A) the red arrows indicate from left to right: a pocket beach, a sea cave, and a sea stack; B) beach formed from outwash material from Bear Glacier. C) rock platforms which are popular haulouts for sea lions; D) alluvium from the metasedimentary cliffs supply sediment for the pocket sand and gravel beaches along this indented coast; E) a sand beach; F) a gravel beach within Aialik Bay; and G) the tidewater Aialik Glacier at the head of Aialik Bay. 


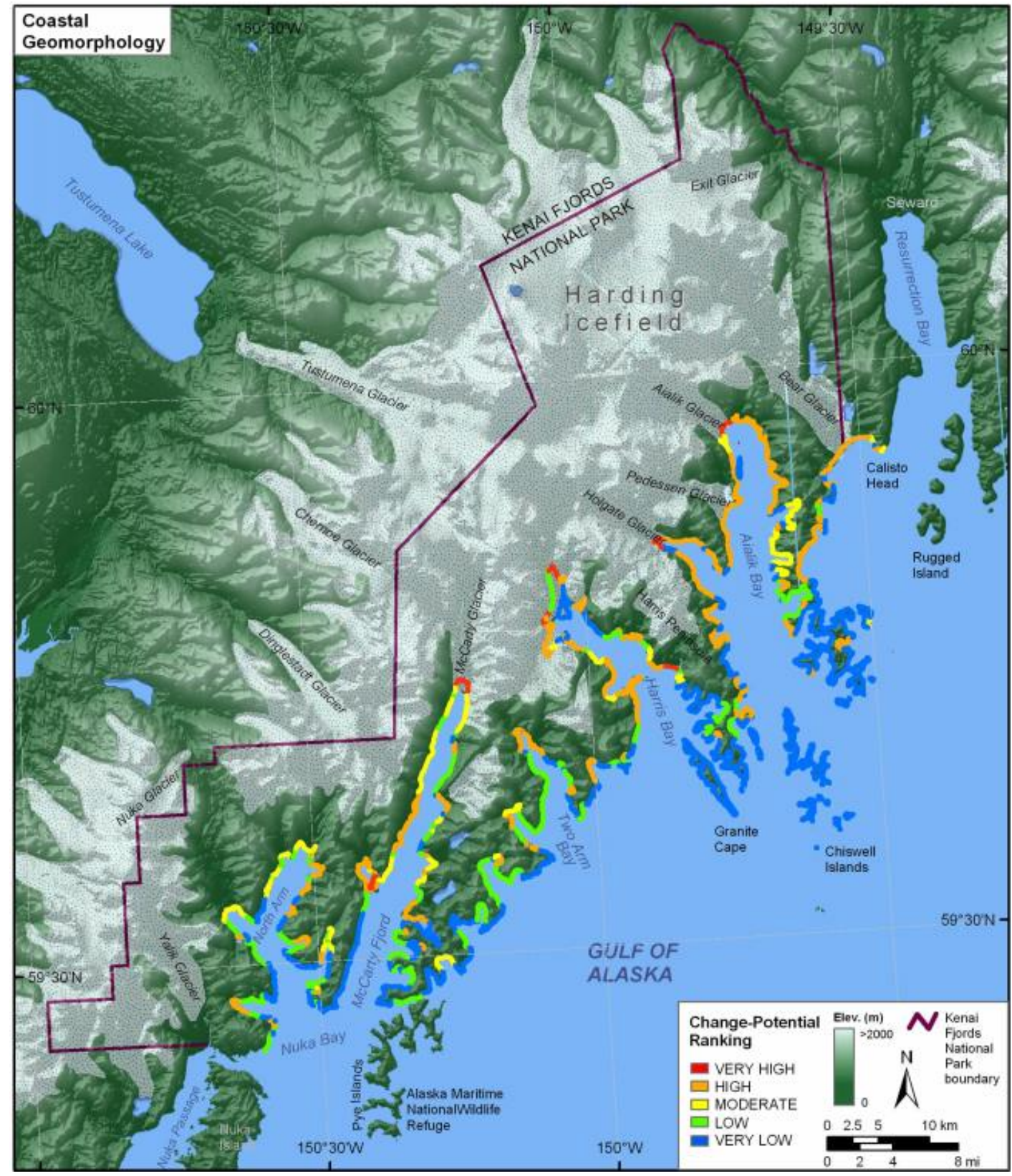

Figure 7. Coastal geomorphology for Kenai Fjords National Park. The colored shoreline represents the variations in coastal geomorphology within the park. The very high change-potential geomorphology is mostly sand beaches, mudflats, or calving tidewater glaciers. High changepotential geomorphology includes gravel and cobble beaches. Moderate change-potential geomorphology consists of alluvial fans and glacial deposits along the shore. Low change-potential geomorphology includes medium cliffs and rock platforms, and very low change-potential areas consist of vertical rock cliffs. 


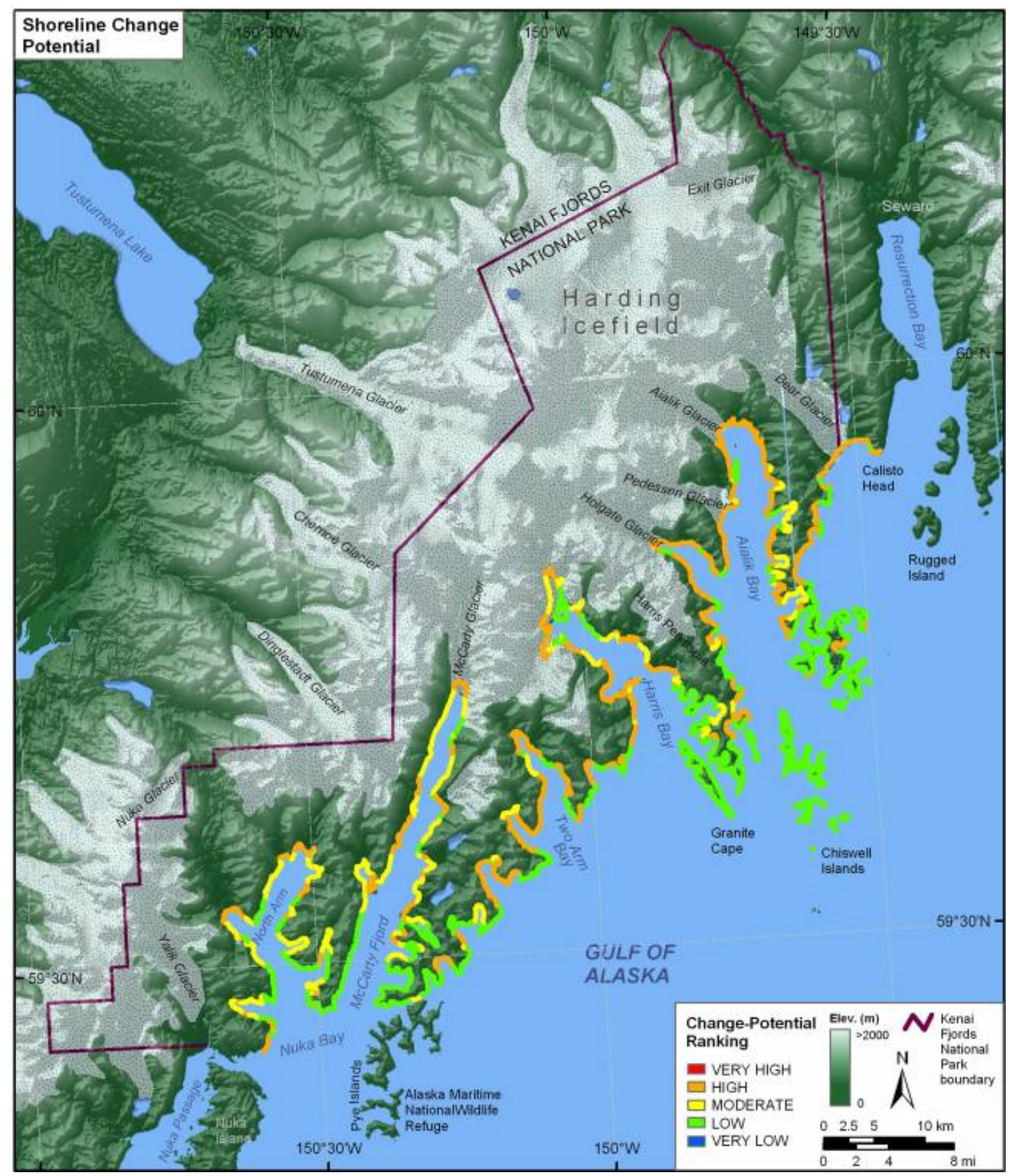

Figure 8. Shoreline change-potential for Kenai Fjords National Park. The colored shoreline represents the estimated potential for shoreline erosion or accretion. Shoreline change-potential for Kenai Fjords range from low change-potential (areas not likely to experience significant shoreline change annually) to high change-potential (areas where shoreline change will likely occur within one year). 


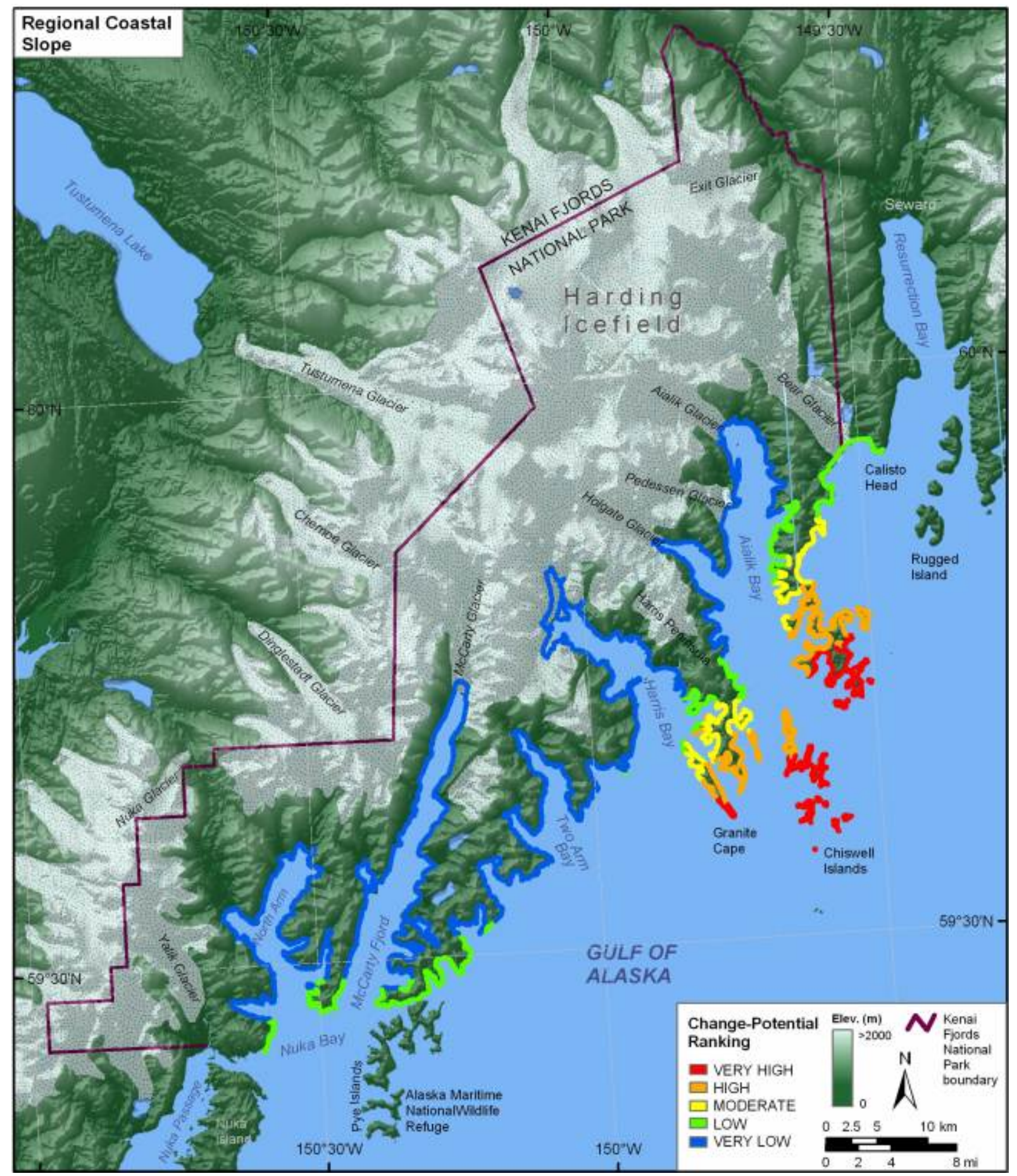

Figure 9. Regional coastal slope for Kenai Fjords National Park. The colored shoreline represents the regional slope of the land, $10 \mathrm{~km}$ landward and seaward of the shoreline. Very high changepotential coastal slope areas are where high mountains are adjacent to deep fjords. Moving seaward, coastal slopes become shallower further into the Gulf of Alaska, where the change in elevation is less dramatic. 


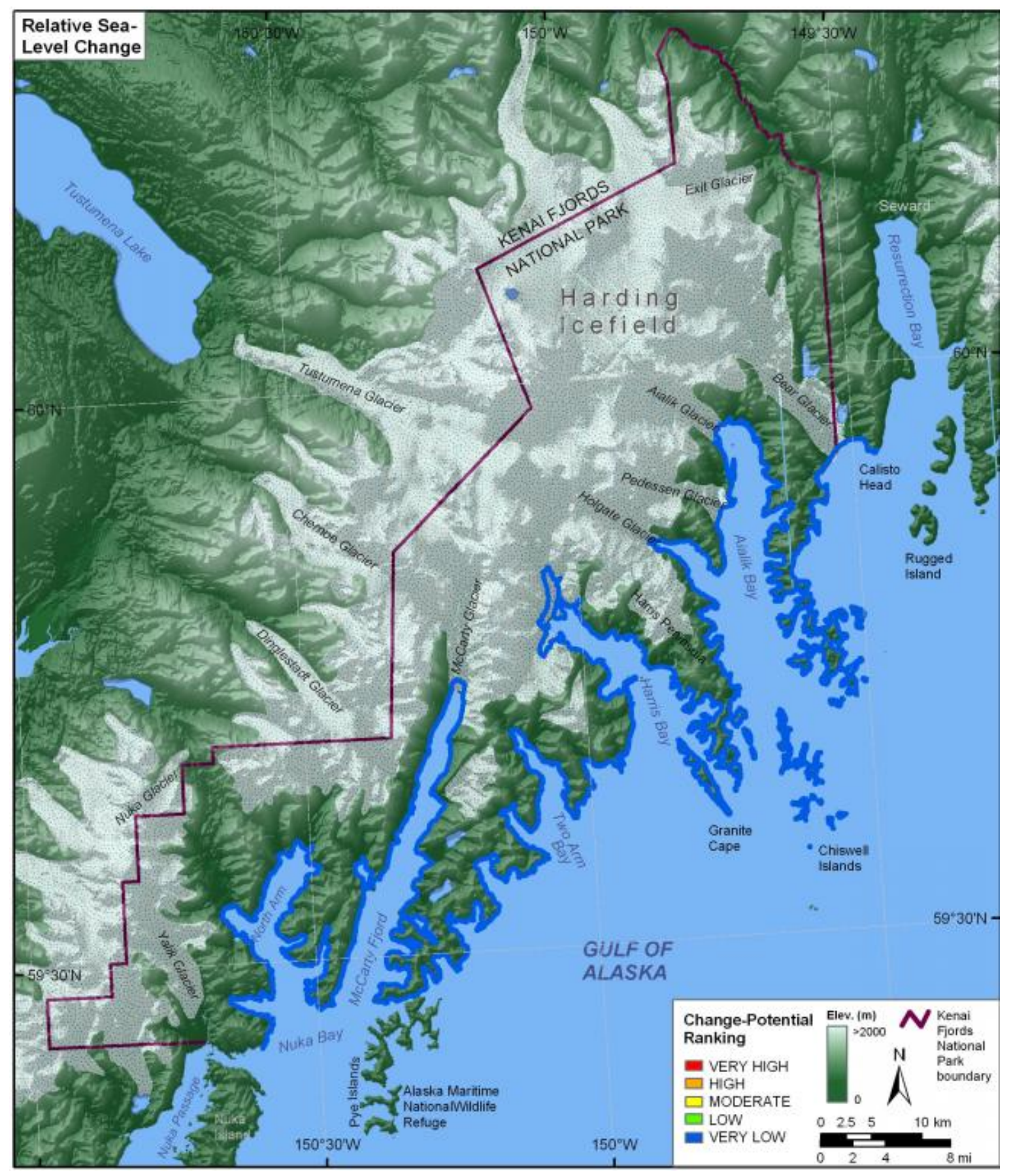

Figure 10. Rate of relative sea-level change for Kenai Fjords National Park. The colored shoreline represents the ranked rate of relative sea-level change for Seward, AK. All of Kenai Fjords is ranked as very low change-potential with respect to relative sea-level change. 


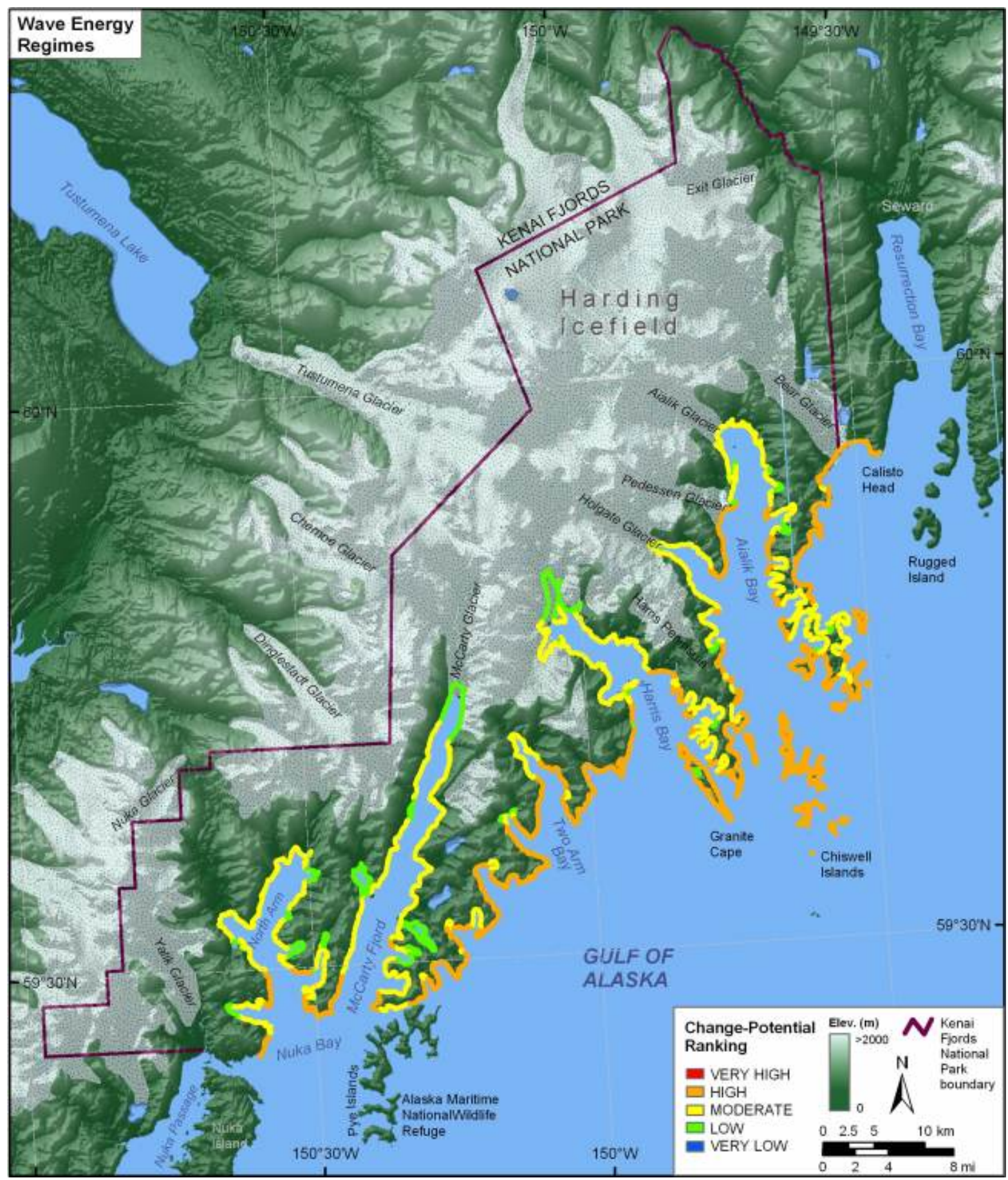

Figure 11. Wave-energy regime for Kenai Fjords National Park. The colored shoreline represents the wave energy regimes within the park. High wave energy areas are located along the exposed coast of the Gulf of Alaska. Wave energy decreases as distance into the fjords increases, or where the shoreline is protected from direct wave approach. 


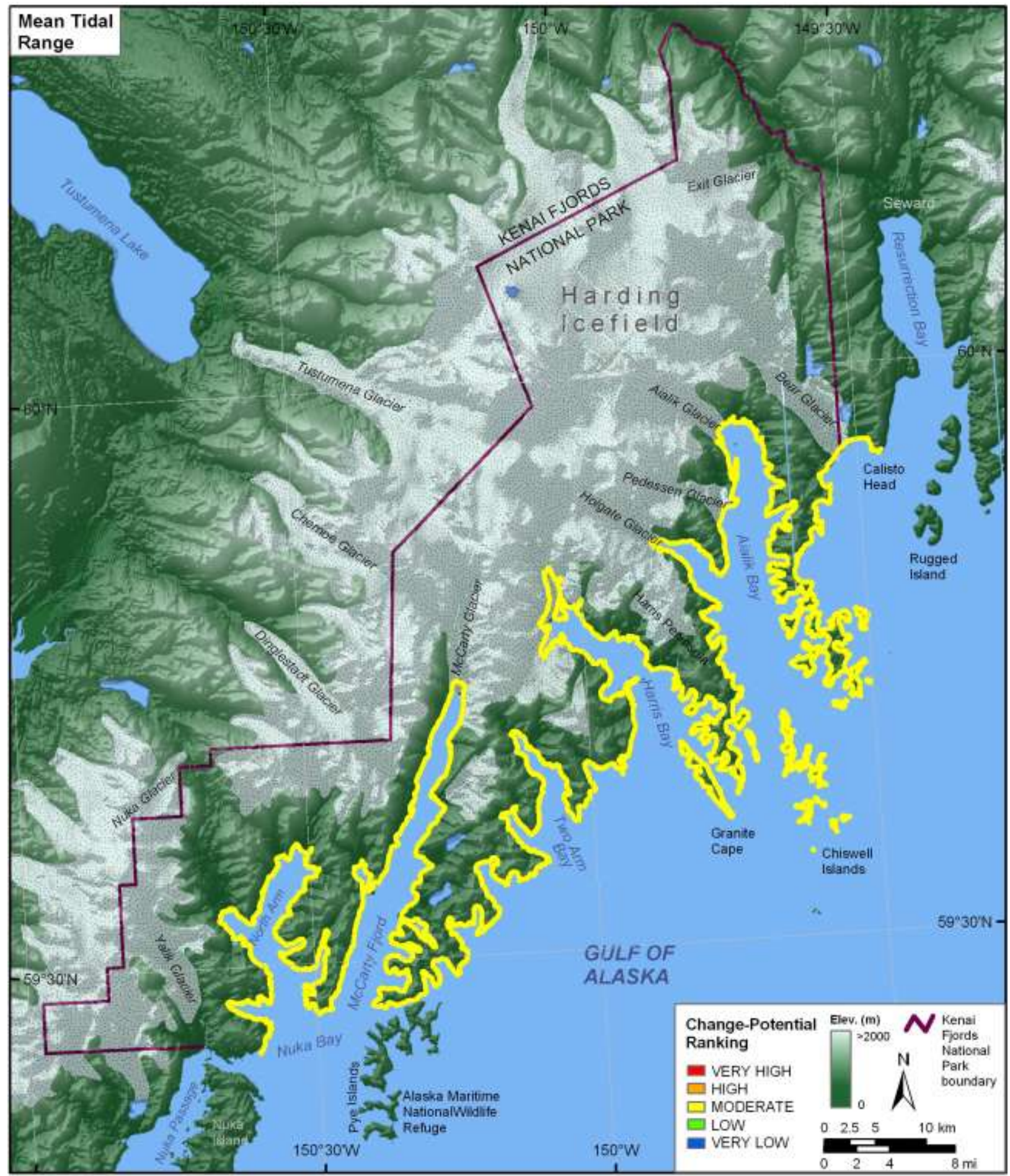

Figure 12. Mean tidal range for the coast of Kenai Fjords National Park. The colored shoreline represents the ranked mean tidal range for Kenai Fjords NP. All of Kenai Fjords NP is ranked as moderate change-potential with respect to tidal range. 


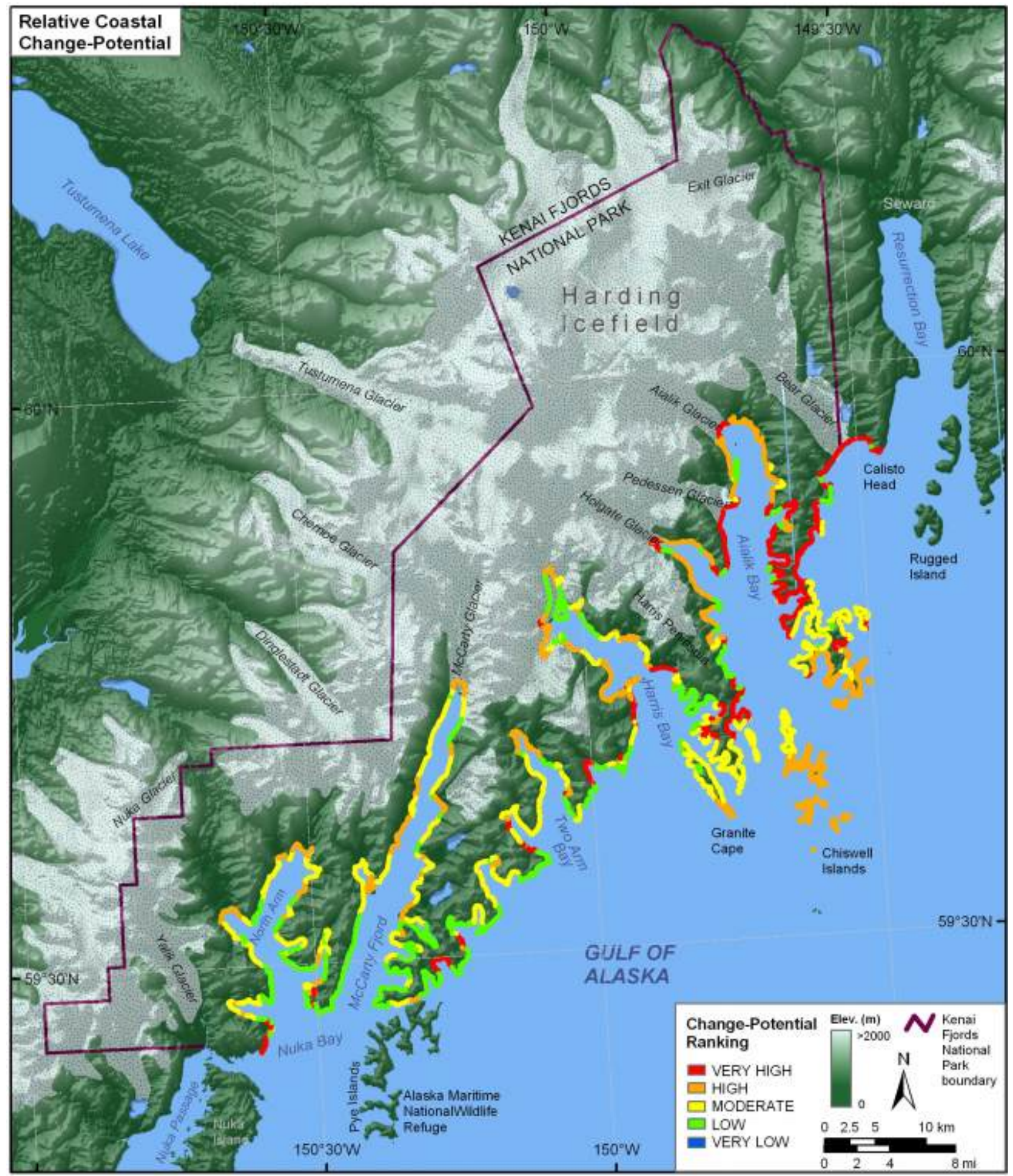

Figure 13. Relative coastal change-potential for Kenai Fjords National Park. The colored shoreline represents the relative coastal change-potential index (CPI) determined from the six variables. The very high change-potential shoreline is located along sandy pocket beaches where shoreline change-potential and significant wave heights are highest. The low change-potential shoreline is located along rock cliffs which are usually within sheltered locations in the fjords. 


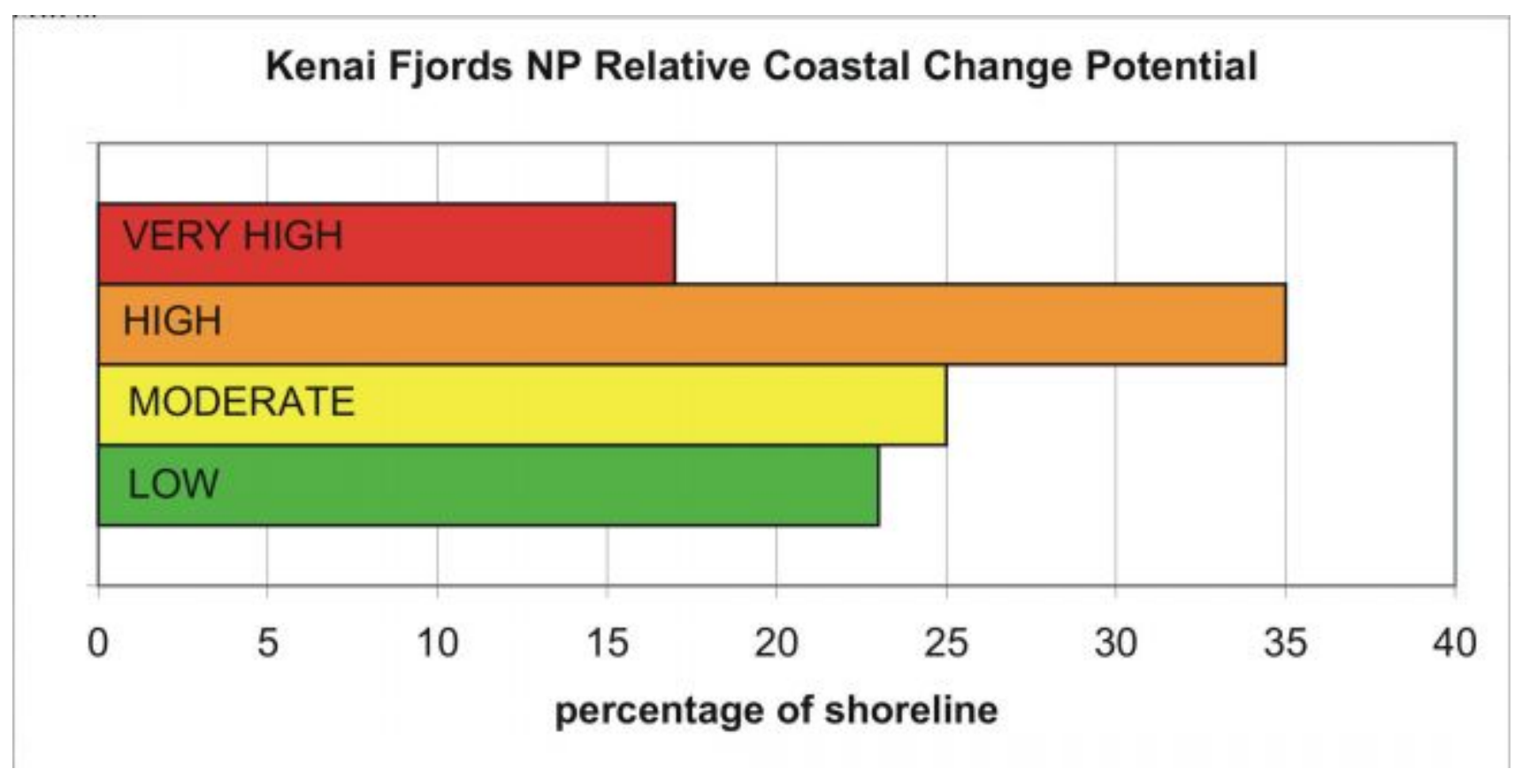

Figure 14. Percentage of Kenai Fjords NP shoreline in each CPI category. 


\section{Tables}

Table 1. Ranges for Vulnerability Ranking of Variables on the U.S. Pacific Coast.

\begin{tabular}{|c|c|c|c|c|c|}
\hline Variable & $\begin{array}{c}\text { Very Low } \\
1\end{array}$ & $\begin{array}{l}\text { Low } \\
2\end{array}$ & $\begin{array}{l}\text { Moderate } \\
\quad 3\end{array}$ & $\begin{array}{c}\text { High } \\
4\end{array}$ & $\begin{array}{c}\text { Very High } \\
5\end{array}$ \\
\hline GEOMORPHOLOGY & $\begin{array}{l}\text { Rocky cliffed } \\
\text { coasts, Fjords }\end{array}$ & $\begin{array}{l}\text { Medium cliffs, } \\
\text { Indented } \\
\text { coasts }\end{array}$ & $\begin{array}{l}\text { Low cliffs, } \\
\text { Glacial drift, } \\
\text { Alluvial plains }\end{array}$ & $\begin{array}{l}\text { Cobble Beaches, } \\
\text { Estuary, Lagoon }\end{array}$ & $\begin{array}{l}\text { Barrier beaches, Sand } \\
\text { beaches, Salt marsh, } \\
\text { Mud flats, Deltas, } \\
\text { Mangrove, Coral reefs }\end{array}$ \\
\hline $\begin{array}{l}\text { ANNUAL SHORELINE } \\
\text { CHANGE } \\
\text { (EROSION/ACCRETION) } \\
\text { POTENTIAL }\end{array}$ & N/A & $\begin{array}{l}\text { Change Not } \\
\text { Likely }\end{array}$ & $\begin{array}{l}\text { Change may or } \\
\text { may not occur }\end{array}$ & Change likely & N/A \\
\hline COASTAL SLOPE (\%) & $>14.7$ & $10.90-14.69$ & $7.75-10.89$ & $4.60-7.74$ & $<4.59$ \\
\hline $\begin{array}{l}\text { RELATIVE SEA-LEVEL } \\
\text { CHANGE }(\mathrm{mm} / \mathrm{yr})\end{array}$ & $0-1.8$ & $1.8-2.5$ & $2.5-3.0$ & $3.0-3.4$ & $>3.4$ \\
\hline $\begin{array}{l}\text { WAVE ENERGY REGIME } \\
\text { (Mann, 1995) }\end{array}$ & N/A & Low & Moderate & High & N/A \\
\hline MEAN TIDE RANGE (m) & $>6.0$ & $4.0-6.0$ & $2.0-4.0$ & $1.0-2.0$ & $<1.0$ \\
\hline
\end{tabular}


Table 2. Sources of Data

\begin{tabular}{|c|c|c|}
\hline Variables & Source & $\begin{array}{c}\text { URL } \\
\text { (Not all sources are downloadable) }\end{array}$ \\
\hline GEOMORPHOLOGY & $\begin{array}{l}\text { Shore-zone classifications of } \\
\text { Kenai Fjords NP published by } \\
\text { NPS Alaska Support Office } \\
\text { (Mann, 1997) }\end{array}$ & http://www.nps.gov/akso/gis/ \\
\hline $\begin{array}{l}\text { ANNUAL SHORELINE } \\
\text { CHANGE } \\
\text { (EROSION/ACCRETION) } \\
\text { POTENTIAL }\end{array}$ & $\begin{array}{l}\text { Wave and Geomorphology data } \\
\text { available through NPS Alaska } \\
\text { Support Office (Mann, 1995; } \\
\text { 1997) }\end{array}$ & http://www.nps.gov/akso/gis/ \\
\hline COASTAL SLOPE $(\%)$ & $\begin{array}{l}\text { NGDC ETOPO2 Global 2' } \\
\text { Elevations }\end{array}$ & http://www.ngdc.noaa.gov/mgg/fliers/01mgg04.html \\
\hline $\begin{array}{l}\text { RELATIVE SEA-LEVEL } \\
\text { CHANGE (mm/yr) }\end{array}$ & $\begin{array}{l}\text { NOAA Technical Report NOS } \\
\text { CO-OPS } 36 \text { SEA LEVEL } \\
\text { VARIATIONS OF THE } \\
\text { UNITED STATES 1854-1999 } \\
\text { (Zervas, 2001) }\end{array}$ & http://www.co-ops.nos.noaa.gov/publications/techrpt36doc.pdf \\
\hline MEAN WAVE HEIGHT (m) & $\begin{array}{l}\text { Wave Energy Regime Database } \\
\text { published by USGS and } \\
\text { available through NPS }\end{array}$ & http://www.nps.gov/akso/gis/ \\
\hline MEAN TIDE RANGE (m) & $\begin{array}{l}\text { NOAA/NOS CO-OPS Historical } \\
\text { Water Level Station Index }\end{array}$ & http://www.co-ops.nos.noaa.gov/usmap.html \\
\hline
\end{tabular}

